HARRAN ÜNIVERSITESI

MÜHENDISLIK DERGisi

HARRAN UNIVERSITY JOURNAL OF ENGINEERING

e-ISSN: $2528-8733$

\section{HARRAN ÜNIVERSITESİ MÜHENDİSLİK DERGİSİ}

HARRAN UNIVERSITY JOURNAL of ENGINEERING

e-ISSN: 2528-8733 (ONLINE)

URL: http://dergipark.gov.tr/humder

Application of Integrated FTA And 5x5 Matrix for the Comprehensive Risk Evaluation of a Project-Based Enterprise

Proje Tabanlı Bir İsletmenin Kapsamlı Risk Değerlendirmesi için Entegre FTA ve $5 x 5$ Matrisinin Uygulanması

Yazar(lar) (Author(s)): Onur DERSE ${ }^{1}$, Elifcan GÖÇMEN POLAT ${ }^{2}$

${ }^{1}$ ORCID ID: 0000-0002-4528-1999

${ }^{2}$ ORCID ID: 0000-0002-0316-281X

Bu makaleye şu şekilde atıfta bulunabilirsiniz (To cite to this article): Derse O., Polat E.G., "Application of Integrated FTA And 5x5 Matrix for the Comprehensive Risk Evaluation of a Project-Based Enterprise", Harran Üniversitesi Mühendislik Dergisi, 6(3): 183-197, (2021).

Erişim linki (To link to this article): http://dergipark.gov.tr/humder/archive 


Mühendislik Dergisi

Araştırma Makalesi

\title{
Application of Integrated FTA And 5x5 Matrix for the Comprehensive Risk Evaluation of a Project-Based Enterprise
}

\author{
Onur DERSE ${ }^{1, *}$, Elifcan GÖÇMEN POLAT ${ }^{2}$ \\ ${ }^{1}$ Department of Management and Organization, Logistics, Tarsus University, Mersin, Turkey, onurderse@tarsus.edu.tr, ORCID: 0000-0002-4528- \\ 1999 \\ ${ }^{2}$ Department of Industrial Engineering, Faculty of Engineering, Munzur University, Tunceli, Turkey, elifcangocmen@munzur.edu.tr, \\ ORCID:0000-0002-0316-281X
}

\section{Makale Bilgisi}

Başvuru: 01/09/2021

Yayın: 30/12/2021

\section{Keywords}

Risk Analysis

Fault Tree Analysi

$5 \times 5$ Matrix

Fishbone Diagram

Anahtar Kelimeler

Risk Analizi

Hata Ağacı Analizi

$5 \times 5$ Matris

Balık Kılçı̆̆ı Diyagramı

\begin{abstract}
Risk management play an important role on preventing failures of any enterprise as it ensures an effective planning and control. Not managing such failures including political, geographical, project, environmental, monetary, human, supply chain risks of the enterprises cause irreparable results. Therefore, there is a need for a comprehensive risk assessment approach regarding qualitative and quantitative risk factors. This paper tackles this need and Fishbone Diagram as a qualitative method and integrated 5x5 Matrix and Fault Tree Analysis methods are used as quantitative methods. The root causes of the risks are examined by taking a project-based enterprise into consideration and evaluated by applying an integrated risk analysis method. Considering the risk analysis results obtained, measures are recommended. An improvement of approximately $24 \%$ has been achieved because of the application of measures. The efficiency of the proposed methods is illustrated in the real-world data of a project-based pipeline manufacturing system and the obtained results demonstrate that practitioners and researchers can easily use these methods to prevent the risks.
\end{abstract}

\section{Proje Tabanlı Bir İşletmenin Kapsamlı Risk Değerlendirmesi için Entegre FTA ve $5 \times 5$ Matrisinin Uygulanması}

\begin{abstract}
$\ddot{\text { Öz }}$
Risk yönetimi, etkin bir planlama ve kontrol sağladığı için herhangi bir ișletmenin başarısızlıklarının önlenmesinde önemli bir rol oynamaktadır. İşletmelerin politik, coğrafi, proje, çevresel, parasal, insani, tedarik zinciri gibi riskleri de dahil olmak üzere bu tür başarısızlıkları yönetememek, telafisi mümkün olmayan sonuçlar doğurmaktadır. Bu nedenle niteliksel ve niceliksel risk faktörlerine ilişskin kapsamlı bir risk değerlendirme yaklaşımına ihtiyaç duyulmaktadır. Bu makale bu ihtiyacı ele almaktadır ve nitel bir yöntem olarak Kılçık Diyagramı ve nicel yöntemler olarak bütünleşmiş $5 \times 5$ Matris ve Hata Ağacı Analizi yöntemleri kullanılmaktadır. Risklerin kök nedenleri, proje bazlı bir işletme göz önünde bulundurularak incelenir ve bütünleşmiş bir risk analizi yöntemi uygulanarak değerlendirilir. Elde edilen risk analizi sonuçları dikkate alınarak önlem alınması önerilir. Tedbirlerin uygulanması sayesinde yaklaşık \%24'lük bir iyileşme sağlanmıştır. Önerilen yöntemlerin etkinliği, proje tabanlı bir boru hattı üretim sisteminin gerçek verilerinde gösterilmektedir ve elde edilen sonuçlar, uygulayıcıların ve araştırmacıların riskleri önlemek için bu yöntemleri kolayca kullanabileceğini göstermektedir.
\end{abstract}

\section{INTRODUCTION (GÍRİŞ)}

A well-functioning risk management method appears as an effective way to improve the processes. A failure in the operations can result operation interruptions. Performing measures for these failures requires effective forecasting of the fault behaviours. Management of the project-based works is difficult, especially for professional projects conducted with international and external customers. Therefore, such enterprises 
seek answers to the following questions: What kind of risks may occur in the enterprise? What could these risks stem from? What is the scale of these dangers? How can I take measures against these dangers? How to manage the risk factors to prevent their effects on the systems? To answer these questions, decision makers analyse the current state of the system and define the main risks and sub-risks. As Fishbone Diagram (FD) is a method frequently used to analyse the root causes, this method is adopted in this paper. Luo et al. [1] develops a FD to analyse the causes of all spherical tank leakage risks. Ilie and Ciocoiu [2] use a FD to analyse the risks of the events with multi causes. In addition, integrated 5x5 Matrix and the Fault Tree Analysis (FTA) methods are developed to evaluate the risks.

To date, many studies have been conducted for risk assessment using various methods. Most studies address the integration of FMEA and FTA methods. To the best of our knowledge, this paper is first to consider the integrated 5x5 Matrix and the FTA. Bertsche [3] addresses that integrating FMEA and FTA can ensure to find more failure modes since the bottom-up method is FMEA and the top-down method is FTA. Derse and Göçmen [4] use the FTA method for the selection of transport modes in their study. Zhang et al. [5] examine a hybrid FTA-FMEA method including three-layers in which a system FTA is conducted to decide failure modes, to find component fault modes, to find fault causes, respectively. Bluvband et al. [6] present an integrated method FTA and FMEA. The method defines the failure events named end effects and a fault tree is formed to obtain all fault modes using FMEA. An interaction matrix is applied to define the high interactions that ensure a corresponding fault tree. Shafiee et al. [7] propose an integrated FTA - FMEA method for safety-critical systems. They weight the minimum cut sets of fault tree analysis to modify the Risk Priority Numbers (RPNs) of FMEA. This integrated method is compared with the risk analysis methods. Martins and Gorschek [8] examine the root causes using FTA for the critical risks and ranking risks performing FMEA for the safety-critical systems. Peeters et al. [9] propose a combining FTA and FMEA method in a recursive manner., in which FTA is conducted to obtain the failure modes and FMEA is used to decide the critical failure modes for a manufacturing system of metal printing. Mutlu and Altuntas [10] address an integrated FMEA and FTA to examine the hazards of a yarn production system. Firstly, the FTA method is applied to find the 57 hazard root causes. FMEA is performed for ranking the risks related to these hazards. Yu et al. [11] present a combining method FMEA- FTA that defines the failure event and forms a fault tree with minimal cut set to decide the basic event. Then, these events are examined by FMEA for finding failure modes. Yazdi et al. [12] use FTA to examine the probabilities of the top event and basic events. Yin et al. [13] propose a fuzzy FTA based on the similarity aggregation method (SAM) to find the failure probabilities of bottom events for a gas storage tank. Wang et al. [14] propose an FTA-based TOPSIS and the triangular fuzzy number using linguistic definitions to assess the probabilities of basic events. Recent papers also address the project-based risk analysis $[15,16]$.

The present paper contributes to this literature by presenting a risk assessment method based on the FTA$5 \times 5$ Matrix to determine and rank the failures and to provide measures for a project-based pipeline manufacturing enterprise. Also, risk failures and root causes of the risks are investigated with both quantitative and qualitative methods. The main and sub-reasons of the risks have been examined by using FD. Then, a risk analysis method is performed using $5 \times 5$ Matrix and FTA methodologies. A classical fault tree forms the probabilities of the top event and intermediate events that are not complete enough, while the integrated FTA-5x5 method can solve the problem using probabilities and severity. $5 \times 5$ matrix is applied to detect failures and depict their effects. The $5 \times 5$ matrix has been performed due to easy applicability [17]. The FTA is conducted to map the relationships of events with their root causes and examines the faults based on root causes and then, risks are ranked using a $5 \times 5$ matrix. The probability for events of FTA is assigned with experts' opinions. The proposed method is considered to an integral part of a project-based manufacturing enterprise.

\section{PROBLEM DEFINITION (PROBLEM TANIMI)}

To understand how the architecture of an enterprise, detailed analysis should be conducted considering internal and external environment. In this context, risk methods are critical aspects in the controlling the processes. Many enterprises have provided solution methods to prevent the hazards and they have applied mitigation or elimination solutions. Most of them face an uncontrolled situation due to lately performed solution methods. The healthcare sector is one of these sectors faced with uncontrolled issues in terms of human living. Thus, proactive methods should be applied to determine the hazards [18]. Project-based enterprises must deal with the risk factors to meet the stakeholder and customer requirements. The presented 
method aims to decrease or eliminate the risks and root causes of these risks depicted in Figure 1. Accordingly, each main risk including political \& geographical, project, environmental, monetary, human, the supply chain of the diagram is divided into has specific sub-risks. FD developed by Kaoru Ishikawa provides root cause analysis of the risks.

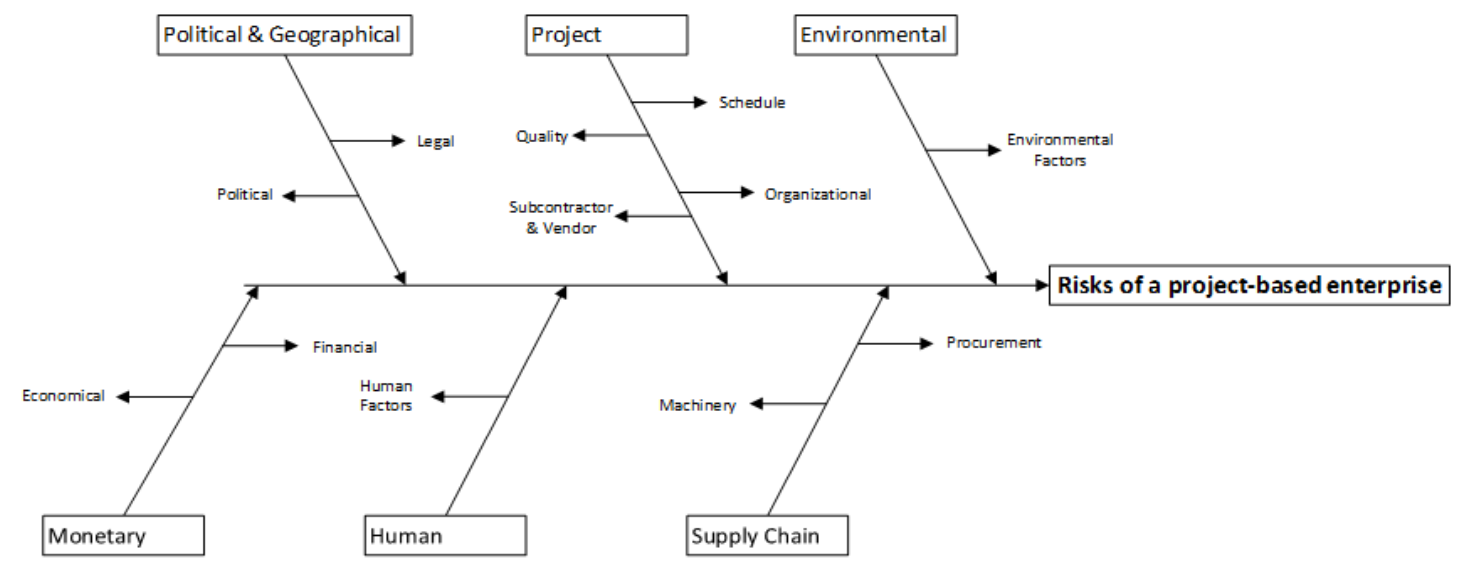

Figure 1. FD for the main and subcategories

Table 1 demonstrates the main and subcategories that are divided into groups using fishbone diagrams, risks, and root causes based on experts' opinions.

Table 1. Root causes of main and sub risks

\begin{tabular}{|c|c|c|c|}
\hline $\begin{array}{l}\text { Main } \\
\text { categories }\end{array}$ & Subcategories & Sub risks & Root Cause of Risk \\
\hline \multirow[t]{2}{*}{$\begin{array}{l}\text { Political \& } \\
\text { Geographical }\end{array}$} & Political & $\begin{array}{l}\text { Negative economic, } \\
\text { political, and military } \\
\text { situations of the country } \\
\text { where the project is } \\
\text { conducted (S1) }\end{array}$ & $\begin{array}{l}\text { 1. Failure to conduct risk analysis of the } \\
\text { country or geography where the project to } \\
\text { be followed }\end{array}$ \\
\hline & & $\begin{array}{l}\text { Failure of subcontractor/ } \\
\text { subcontractors to fulfil } \\
\text { their legal obligations (S2) }\end{array}$ & $\begin{array}{l}\text { 1. Various responsibilities imposed on the } \\
\text { employers, as the subcontractors do not } \\
\text { fulfil the obligations related to Social }\end{array}$ \\
\hline \multirow{2}{*}{$\begin{array}{l}\text { Political \& } \\
\text { Geographical }\end{array}$} & Legal & & Security Institution \\
\hline & & & $\begin{array}{l}\text { 2. The reason for not paying the } \\
\text { subcontractor is that they cannot receive } \\
\text { their payments on time. }\end{array}$ \\
\hline Project & Schedule & $\begin{array}{l}\text { The supplier alternatives } \\
\text { are not enough (S3) }\end{array}$ & $\begin{array}{l}\text { 1. Employer's approval for a limited number } \\
\text { of suppliers }\end{array}$ \\
\hline \multirow[t]{2}{*}{ Project } & Schedule & Deviating of production & 1. Lack of planning \\
\hline & & $\begin{array}{l}\text { plan related with pipeline, } \\
\text { fittings, steel materials are } \\
\text { not available at the } \\
\text { scheduled time (S4) }\end{array}$ & $\begin{array}{l}\text { 2. Disruptions in the purchasing process, } \\
\text { 3. Supplier-related disruptions / working } \\
\text { with a limited number of suppliers }\end{array}$ \\
\hline Project & Schedule & $\begin{array}{l}\text { Risks arising from the } \\
\text { preparation of the project } \\
\text { for the project's / client's } \\
\text { own business objectives, } \\
\text { instead of taking the } \\
\text { factory's opinion in } \\
\text { production planning with } \\
\text { realistic assumptions (S5) }\end{array}$ & $\begin{array}{l}\text { 1. Forming the production plan by ignoring } \\
\text { the production dynamics, } \\
\text { 2. Deviation from the plan, taking deadline } \\
\text { early by the customer } \\
\text { 3. Late revision requests }\end{array}$ \\
\hline
\end{tabular}




\begin{tabular}{|c|c|c|c|}
\hline Project & Schedule & $\begin{array}{l}\text { Lack of stock or late } \\
\text { supply of spare parts } \\
\text { required for CNC } \\
\text { machines and } \\
\text { machines(S6) }\end{array}$ & $\begin{array}{l}\text { 1. All the parts come from abroad due to the } \\
\text { distributors not working with stock } \\
\text { 2. Since CNC machines and machines are } \\
\text { old models, the parts are not produced / } \\
\text { replaced by the manufacturer } \\
\text { 3. Unexpected failure due to excessive } \\
\text { working intensity due to the lack of } \\
\text { alternative of some machines }\end{array}$ \\
\hline Project & Schedule & $\begin{array}{l}\text { Risks encountered in the } \\
\text { revision request process } \\
\text { (S7) }\end{array}$ & $\begin{array}{l}\text { 1. Revision pictures due to changes in } \\
\text { design, } \\
\text { 2. Production is not finished in time or } \\
\text { under revision } \\
\text { 3. The projects are constantly revised by the } \\
\text { designer or engineering }\end{array}$ \\
\hline Project & Schedule & $\begin{array}{l}\text { The detailed list of } \\
\text { materials used in the } \\
\text { project does not arrive on } \\
\text { time or is missing ( } \mathrm{S} 8 \text { ) }\end{array}$ & $\begin{array}{l}\text { 1. The materials used in the project cannot } \\
\text { be determined at work. }\end{array}$ \\
\hline \multirow[t]{3}{*}{ Project } & Schedule & $\begin{array}{l}\text { Material and personal / } \\
\text { hour loss due to faulty } \\
\text { manufacturing (S9) }\end{array}$ & $\begin{array}{l}\text { 1. Inadequate personnel selection } \\
\text { 2. Incorrect / missing design works } \\
\text { 3. Faults in processing raw material } \\
\text { 4. Welding errors, paint errors } \\
\text { 5. Failure to operate / implement the control } \\
\text { mechanism sufficiently } \\
\text { 6. Deficiencies in the planning of the } \\
\text { process } \\
\text { 7. Human error }\end{array}$ \\
\hline & & $\begin{array}{l}\text { Risks in the maintenance / } \\
\text { repair process (S10) }\end{array}$ & $\begin{array}{l}\text { 1. Periodic maintenance is not conducted } \\
\text { regularly }\end{array}$ \\
\hline & & & $\begin{array}{l}\text { 2. Operator maintenance is not conducted } \\
\text { regularly }\end{array}$ \\
\hline Project & Schedule & & $\begin{array}{l}\text { 3. Failure ignored by the operator } \\
\text { 4. Loss of time in service / spare parts needs } \\
\text { due to machine manufacturers are from } \\
\text { abroad }\end{array}$ \\
\hline \multirow[t]{2}{*}{ Project } & Organizational & $\begin{array}{l}\text { Loss of time, additional } \\
\text { cost, and labour loss due } \\
\text { to the incomplete raw } \\
\text { material and material from } \\
\text { the customer / Project } \\
\text { (S11) }\end{array}$ & $\begin{array}{l}\text { 1. The quantity control of the purchased } \\
\text { product is not conducted according to the } \\
\text { delivery plan } \\
\text { 2. The product quality and features are not } \\
\text { confirmed suitable for the order } \\
\text { 3. The product is not delivered on the } \\
\text { delivery date specified in the order }\end{array}$ \\
\hline & Organizational & $\begin{array}{l}\text { Risks related with } \\
\text { deficiencies in stock } \\
\text { management (S12) }\end{array}$ & $\begin{array}{l}\text { 1. Instead of giving the product, which is } \\
\text { about to expire, giving the longer one, } \\
\text { 2. Lack of physical control on expiration } \\
\text { dates }\end{array}$ \\
\hline & & & $\begin{array}{l}\text { 3. Uncontrolled transfer from stock to } \\
\text { manufacturing }\end{array}$ \\
\hline Project & $\begin{array}{l}\text { Subcontractor } \\
\& \text { Vendor }\end{array}$ & $\begin{array}{l}\text { Loss of time due to lack of } \\
\text { firms for galvanizing } \\
\text { processes (S13) }\end{array}$ & $\begin{array}{l}\text { 1. Small enterprises in the region are not } \\
\text { able to meet their galvanizing needs. } \\
\text { 2. Lack of } 20 \text { meters pool }\end{array}$ \\
\hline Project & Quality & $\begin{array}{l}\text { Not satisfying the } \\
\text { employer of the quality of } \\
\text { the productions (S14) }\end{array}$ & $\begin{array}{l}\text { 1. No more attention to quality standards } \\
\text { than competitors }\end{array}$ \\
\hline
\end{tabular}




\begin{tabular}{|c|c|c|c|}
\hline Environmental & $\begin{array}{l}\text { Environmental } \\
\text { Factors }\end{array}$ & $\begin{array}{l}\text { Loss of opportunity and } \\
\text { risk of not getting a job } \\
\text { due to inability to respond } \\
\text { to different needs to } \\
\text { changes in trends (S15) }\end{array}$ & $\begin{array}{l}\text { 1. Need for strategic plan, } \\
\text { 2 Sectoral trends are not being followed } \\
\text { 3. Requests with one-piece modules (high } \\
\text { tonnage and bulky product demands) }\end{array}$ \\
\hline Environmental & $\begin{array}{l}\text { Environmental } \\
\text { Factors }\end{array}$ & $\begin{array}{l}\text { The structure of the } \\
\text { platforms due to the lack } \\
\text { of a manufacturing site at } \\
\text { the port and logistics } \\
\text { constraints (S16) }\end{array}$ & $\begin{array}{l}\text { 1. Inability to meet the need due to the } \\
\text { available infrastructure, } \\
\text { 2. Problems to get a job due to the available } \\
\text { port structure and logistics constraints, } \\
\text { 3. The emergence of large tonnage platform } \\
\text { needs by technology }\end{array}$ \\
\hline Environmental & $\begin{array}{l}\text { Environmental } \\
\text { Factors }\end{array}$ & $\begin{array}{l}\text { Natural disasters / disaster } \\
\text { risks (S17) }\end{array}$ & $\begin{array}{l}\text { 1. Lack of a procedure where the need for } \\
\text { physical security is defined } \\
\text { 2. Employees are not conscious } \\
\text { 3. The factory has not taken the necessary } \\
\text { measures for natural disasters and disasters }\end{array}$ \\
\hline Environmental & $\begin{array}{l}\text { Environmental } \\
\text { Factors }\end{array}$ & $\begin{array}{l}\text { Failure to comply with the } \\
\text { requirements of the } \\
\text { Turkish Environmental } \\
\text { Law No. } 2872 \text { (S18) }\end{array}$ & $\begin{array}{l}\text { 1. The regulations of the Turkish } \\
\text { Environmental Law No. } 2872 \text { do not have a } \\
\text { systematic method to follow } \\
\text { 2. The staff in the OHS-Environment } \\
\text { organization do not have sufficient } \\
\text { experience for environmental regulations } \\
\text { 3. Lack of staff responsible for } \\
\text { environmental regulations } \\
\text { 4. Environmental officers do not have } \\
\text { sufficient knowledge and education. } \\
\text { 5. Managers and authorized supervisors are } \\
\text { insufficient about environmental risk } \\
\text { awareness, and they are not sensitive about } \\
\text { environmental issues. } \\
\text { 6. Not enough budget can be allocated to } \\
\text { take the measures required by } \\
\text { environmental legislation } \\
\text { 7. Employees do not know about } \\
\text { environmental management risks and take } \\
\text { necessary precautions. }\end{array}$ \\
\hline Environmental & $\begin{array}{l}\text { Environmental } \\
\text { Factors }\end{array}$ & $\begin{array}{l}\text { The risks based on the } \\
\text { working conditions; (S19) } \\
\text { - Particle in the air, } \\
\text { - Sound, noise }\end{array}$ & $\begin{array}{l}\text { 1. The necessary precautions are not taken } \\
\text { to ensure adequate working conditions }\end{array}$ \\
\hline Environmental & $\begin{array}{l}\text { Environmental } \\
\text { Factors }\end{array}$ & $\begin{array}{l}\text { Risks due to proximity to } \\
\text { the war zone (sabotage, } \\
\text { etc.) (S20) }\end{array}$ & $\begin{array}{l}\text { 1. The factory is close to the war zone, } \\
\text { 2. Close to Incirlik air base }\end{array}$ \\
\hline Monetary & Economical & $\begin{array}{l}\text { Loss due to open positions } \\
\text { (S21) }\end{array}$ & 1. Open position \\
\hline Monetary & Economical & $\begin{array}{l}\text { Increase in the price of } \\
\text { materials (raw materials) } \\
\text { (S22) }\end{array}$ & $\begin{array}{l}\text { 1. Price increase due to market conditions } \\
\text { 2. Price increase due to currency } \\
\text { movements } \\
\text { 3. Price increase due to political instability } \\
\text { in the region }\end{array}$ \\
\hline Monetary & Economical & $\begin{array}{l}\text { Risks due to the possibility } \\
\text { of changes in oil prices } \\
\text { (S23) }\end{array}$ & 1. Unexpected changes in oil prices \\
\hline Monetary & Financial & $\begin{array}{l}\text { Cost increases since } \\
\text { payment method is not }\end{array}$ & $\begin{array}{l}\text { 1. The assumption that the procurement of } \\
\text { goods will be cash during the bidding }\end{array}$ \\
\hline
\end{tabular}




\begin{tabular}{|c|c|c|c|}
\hline & & $\begin{array}{l}\text { realized in the purchase of } \\
\text { material (S24) }\end{array}$ & $\begin{array}{l}\text { process, does not occur during the } \\
\text { procurement of goods, } \\
\text { 2. Changes in cash / forward purchase } \\
\text { forecasts in proposal / realization periods } \\
\text { for liquidity management }\end{array}$ \\
\hline Monetary & Financial & $\begin{array}{l}\text { Login to the accounting } \\
\text { system If non-commercial } \\
\text { e-invoices are organized } \\
\text { incorrectly (S25) }\end{array}$ & 1. Incorrect arrangement of e-invoice \\
\hline Monetary & Financial & $\begin{array}{l}\text { No purchase budget or } \\
\text { budget analysis is not } \\
\text { possible (S26) }\end{array}$ & $\begin{array}{l}\text { 1. Starting the purchasing process without } \\
\text { exploring the budget possibilities, } \\
\text { 2. Failure to perform budget / realization } \\
\text { analysis }\end{array}$ \\
\hline Monetary & Financial & $\begin{array}{l}\text { Credit risk: The credit risk } \\
\text { due to receiving late or not } \\
\text { at all by customers ( } 227)\end{array}$ & $\begin{array}{l}\text { 1. Macro-economic conditions deteriorating } \\
\text { 2. Customer's default behaviours } \\
\text { 3. Cessation of work in the customer's } \\
\text { country due to terrorism / war }\end{array}$ \\
\hline Human & $\begin{array}{l}\text { Human } \\
\text { Factors }\end{array}$ & $\begin{array}{l}\text { Failure to complete the } \\
\text { works required within the } \\
\text { scope of "Turkish Personal } \\
\text { Data Protection Law" } \\
\text { (S28) }\end{array}$ & $\begin{array}{l}\text { 1. Inadequate legislative follow-up, detailed } \\
\text { company risk assessment method not } \\
\text { defined within the scope of Turkish Law on } \\
\text { Protection of Personal Data } \\
\text { 2. Since legal processes are based on wet } \\
\text { signature, retrospective information must be } \\
\text { stored. } \\
\text { 3. Obligation to keep some personal } \\
\text { information based on the regulations in the } \\
\text { Company, except for the relevant law. }\end{array}$ \\
\hline Human & $\begin{array}{l}\text { Human } \\
\text { Factors }\end{array}$ & $\begin{array}{l}\text { Risk of increasing the } \\
\text { burden of leave because of } \\
\text { company employees not } \\
\text { using their annual leave } \\
\text { rights (S29) }\end{array}$ & $\begin{array}{l}\text { 1. Factory employees are not obliged to use } \\
\text { leave }\end{array}$ \\
\hline Human & $\begin{array}{l}\text { Human } \\
\text { Factors }\end{array}$ & $\begin{array}{l}\text { Sub-employers not } \\
\text { employing full-time } \\
\text { occupational safety } \\
\text { personnel (S30) }\end{array}$ & $\begin{array}{l}\text { 1. Sub-employers are not required by } \\
\text { contract } \\
\text { 2. Sub-employer managers and authorized } \\
\text { supervisors are not sensitive and conscious } \\
\text { about occupational health and safety }\end{array}$ \\
\hline Human & $\begin{array}{l}\text { Human } \\
\text { Factors }\end{array}$ & $\begin{array}{l}\text { Failure to comply with the } \\
\text { requirements of Turkish } \\
\text { Law } 6331 \text { on Occupational } \\
\text { Health and Safety (S31) }\end{array}$ & $\begin{array}{l}\text { 1. The regulations of the Turkish } \\
\text { Occupational Health and Safety Law No. } \\
6331 \text { do not have a systematic to follow. } \\
\text { 2. The personnel in the OHS organization } \\
\text { do not have sufficient experience and } \\
\text { knowledge, } \\
\text { 3. The number of OHS personnel is } \\
\text { insufficient, } \\
\text { 4. Insufficient budget for OHS measures }\end{array}$ \\
\hline Human & $\begin{array}{l}\text { Human } \\
\text { Factors }\end{array}$ & $\begin{array}{l}\text { Risk in case of fire / } \\
\text { explosion due to } \\
\text { "Emergency Response } \\
\text { Plan" outdated or not } \\
\text { known to employees (S32) }\end{array}$ & $\begin{array}{l}\text { 1.Failure to apply industry regulations } \\
\text { regarding fire / explosion within the scope } \\
\text { of Turkish Occupational Health and Safety } \\
\text { Law No. } 6331 \text {. } \\
\text { 2. No protective and limiting measures have } \\
\text { been taken for flammable and explosive } \\
\text { substances that may cause fire and } \\
\text { explosion. } 3 \text {. The occupational safety }\end{array}$ \\
\hline
\end{tabular}




$\begin{array}{lll}\text { Human } & \text { Human } & \text { Poisoning (Food poisoning } \\ \text { Fecause of presenting } \\ \text { unhealthy food) (S33) }\end{array}$

$\begin{array}{lll}\text { Human } & \begin{array}{l}\text { Human } \\ \text { Factors }\end{array} & \begin{array}{l}\text { Penalties since work } \\ \text { accidents at the factory are } \\ \text { not reported on time (S34) }\end{array} \\ \text { Supply Chain } \quad \text { Machinery } & \begin{array}{l}\text { Decreased competitiveness } \\ \text { due to worn and aged } \\ \text { benches (S35) }\end{array}\end{array}$

Supply Chain Machinery Due to software error of CNC machines, posture / quality impairment is experienced (S36) Malfunction of pre-

Supply Chain Machinery fabrication machinery and equipment (S37)

Supply Chain Procurement personnel in the OHS organization do not have sufficient experience and knowledge. 4. Lack of adequate control over fire / explosion and lack of risk management. 5. Insufficient budget has not been allocated to take protective and restrictive measures, which must be taken in accordance with legislation and regulations that may cause fire and explosion.

6. Employees do not have information about fire and explosion risks and take precautions.

1. Lack of food safety management system

2. The absence and implementation of hygiene rules

3. Lack of risk management and insufficient audits.

4. The staff and kitchen staff do not have enough experience and knowledge.

5. Management and authorized supervisors do not have awareness about hygiene and food safety and are not sensitive to these issues.

6. The budget has not been allocated to provide the necessary equipment / equipment and materials to apply food safety and hygiene rules.

1. Failure to employ qualified personnel in subcontractors.

1.Decreased production speed and cutting / drilling quality due to worn preliminary machine tools

2. Increased costs due to low cutting / drilling quality and speed

1. Lack of maintenance on some CNC machines software bases

2. User error

1. Operator Errors

2. Periodic maintenance is not done properly,

4. Exceeding the lifetime of the equipment

1. Lack of management system,

2. Lack of a systematic archive,

3. Failure to systematically save information accumulation / system not being installed functions of the factory (S38)

\section{COMBINING THE FD AND THE 5X5 MATRIX-BASED FTA (FD VE 5X5 MATRIX TABANLI FTA'NIN BİRLEŞTIRILLMESI)}

The first step is employing the FD, where analysis and grouping of root causes are defined on the diagram. The second stage is 5x5 matrix-based FTA that provides both occurrence and severity impact of the risks on the tree. The $5 \times 5$ Matrix method is a method in which probability is multiplied by severity and likelihood 
risk scores are categorized. FTA is proposed either quantitatively or qualitatively [19]. FTA identifies the basic events linked with top events qualitatively, defines root causes for failures with probabilities quantitatively [20]. FTA is a practical method of risk assessment to eliminate and control hazards [21] and uses Boolean algebra a top event and basic events that are connected using logic gates [22]. The basic stages of the fault tree analysis are examining the system and define this system, constructing the fault tree, identifying the top event, assigning the intermediate and bottom events linked with the top event, connecting those events by OR and AND gates [20]. Gates depicts that how failures cause system failures [23]. The proposed methodology is presented in the following Figure 2.

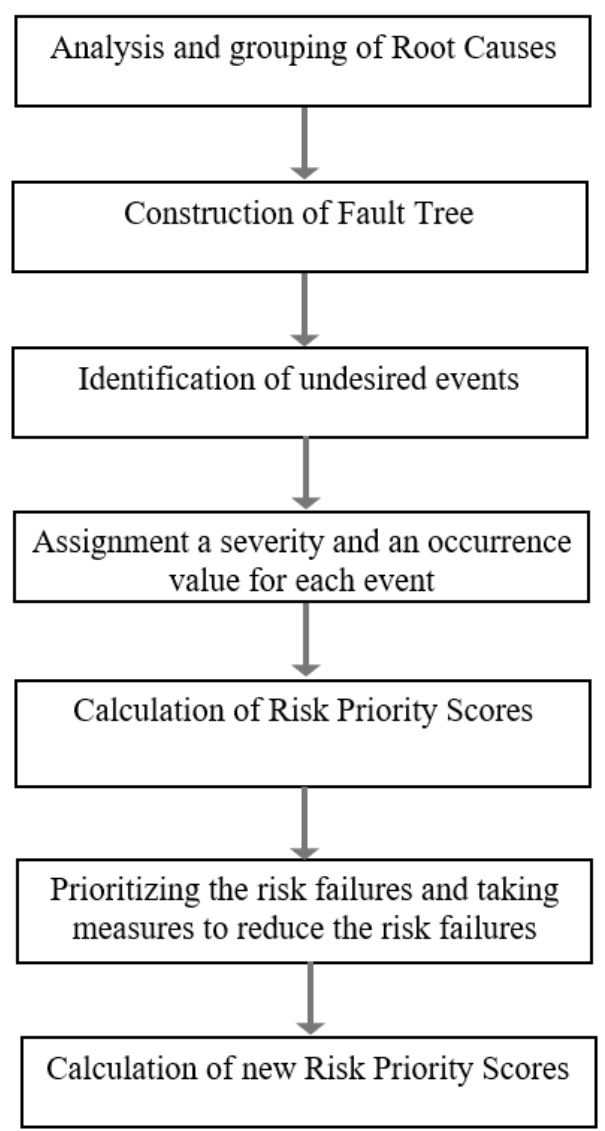

Figure 2. Stages of the implementation of the proposed methods

\section{RESULTS (SONUÇLAR)}

The presented framework is employed to demonstrate its effective risk assessment of the project-based enterprise. The outputs of the FD method mentioned in the problem statement are included in the $5 \times 5$ matrix. The values given are shown in Table 2 . Table 2 demonstrates the risk scores obtained by multiplying the occurrence and severity parameters of risks.

Table 2. Risk scores obtained by $5 X 5$ matrix

\begin{tabular}{|c|c|c|c|c|c|c|}
\hline $\begin{array}{l}\text { Main } \\
\text { categories }\end{array}$ & Subcategories & Risk & $\begin{array}{l}\text { FTA } \\
\text { Code }\end{array}$ & Severity & Occurrence & $\begin{array}{l}\text { Risk } \\
\text { Score }\end{array}$ \\
\hline Project & Schedule & S1 & R111 & 5 & 3 & 15 \\
\hline Project & Schedule & S2 & R112 & 5 & 4 & 20 \\
\hline Project & Schedule & S3 & R113 & 5 & 3 & 15 \\
\hline Project & Schedule & S4 & R114 & 5 & 4 & 20 \\
\hline Project & Schedule & S5 & R115 & 4 & 4 & 16 \\
\hline Project & Schedule & S6 & R116 & 5 & 2 & 10 \\
\hline Project & Schedule & S7 & R117 & 5 & 4 & 20 \\
\hline Project & Schedule & S8 & $\mathrm{R} 118$ & 4 & 4 & 16 \\
\hline
\end{tabular}




\begin{tabular}{lllllll}
\hline Project & Organizational & S9 & R121 & 4 & 3 & 12 \\
Project & Organizational & S10 & R122 & 3 & 3 & 9 \\
Project & Subcontractor \& Vendor & S11 & R13 & 2 & 2 & 4 \\
Project & Quality & S12 & R14 & 2 & 2 & 4 \\
Political \& & Political & S13 & R21 & 2 & 2 & 4 \\
Geographical & & & & \\
Political \& & Legal & S14 & 2 & 2 & 4 \\
Geographical & & & & \\
Environmental & Environmental Factors & S15 & R31 & 4 & 4 & 16 \\
Environmental & Environmental Factors & S16 & R32 & 4 & 4 & 16 \\
Environmental & Environmental Factors & S17 & R33 & 5 & 3 & 15 \\
Environmental & Environmental Factors & S18 & R34 & 5 & 2 & 10 \\
Environmental & Environmental Factors & S19 & R35 & 3 & 2 & 6 \\
Environmental & Environmental Factors & S20 & R36 & 5 & 2 & 10 \\
Monetary & Economical & S21 & R411 & 5 & 3 & 15 \\
Monetary & Economical & S22 & R412 & 3 & 5 & 15 \\
Monetary & Economical & S23 & R413 & 5 & 5 & 25 \\
Monetary & Financial & S24 & R421 & 3 & 3 & 9 \\
Monetary & Financial & S25 & R422 & 2 & 2 & 4 \\
Monetary & Financial & S26 & R423 & 3 & 3 & 9 \\
Monetary & Financial & S27 & R424 & 4 & 2 & 8 \\
Human & Human Factors & S28 & R51 313 & 3 & 9 \\
Human & Human Factors & S29 & R52 & 5 & 3 & 15 \\
Human & Human Factors & S30 & R53 & 5 & 2 & 10 \\
Human & Human Factors & S31 & R54 & 5 & 2 & 10 \\
Human & Human Factors & S32 & R55 & 5 & 2 & 10 \\
Human & Human Factors & S33 & R56 & 5 & 2 & 10 \\
Human & Human Factors & S34 & R57 & 4 & 2 & 8 \\
Supply Chain & Machinery & S35 & R611 & 4 & 3 & 12 \\
Supply Chain & Machinery & S36 & R612 & 5 & 3 & 15 \\
Supply Chain & Machinery & S37 & R613 & 4 & 2 & 8 \\
Supply Chain & Procurement & R62 & 4 & 3 & 12 \\
\hline
\end{tabular}

Figure 3 shows the $5 \times 5$ based fault tree codes to assign the basic, intermediate, and top events on the tree. The connection between the risks is analysed by this diagram. The links of the root causes are derived by FD results. 


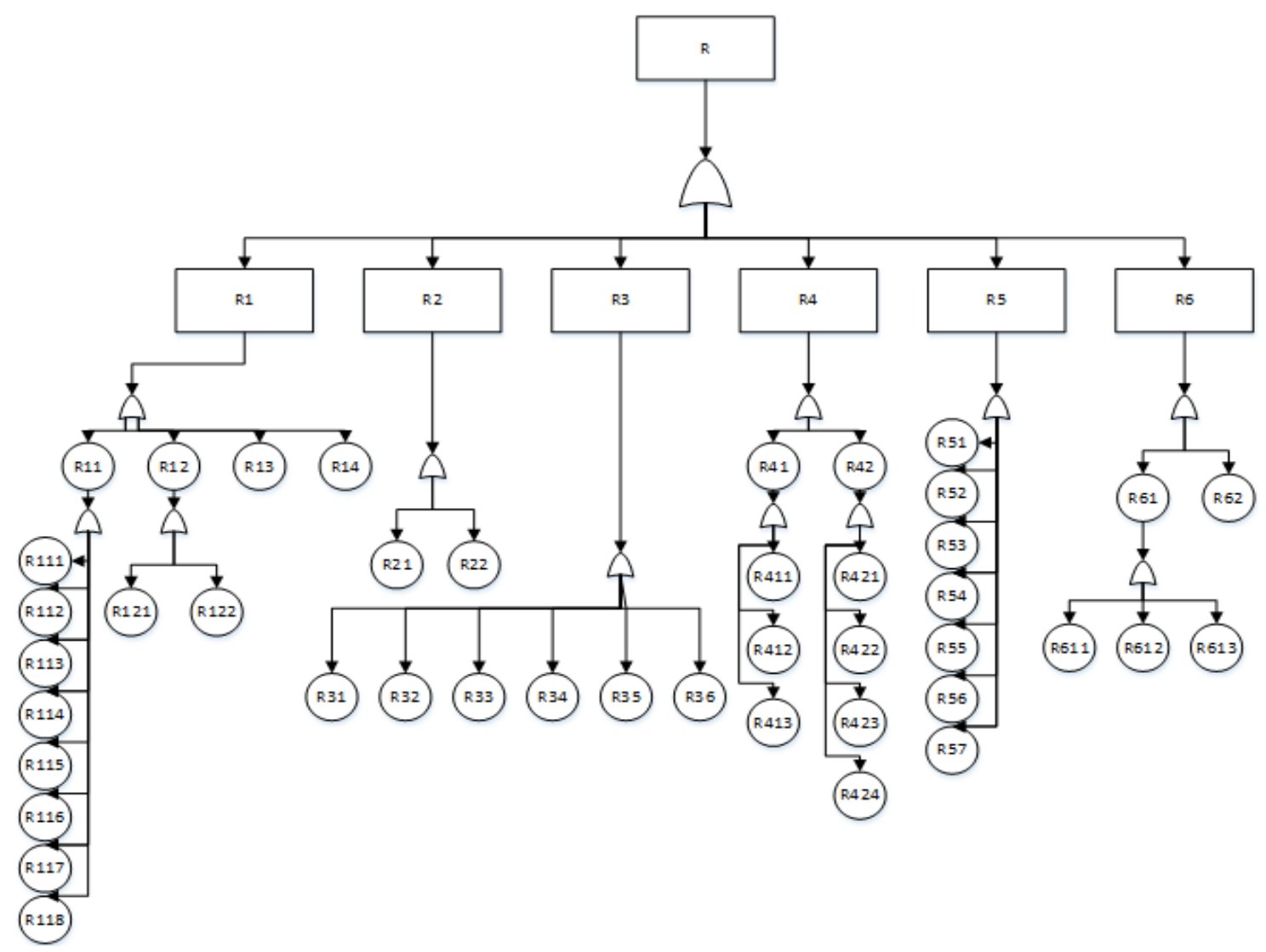

Figure 3. Fault tree based on 5 X5 Matrix

Figure 4 shows the result of multiplying occurrence and severity values for bottom events and conducting the FTA method by using OR and AND gates. The important measures of the system are given in this figure. Risks with the highest value are R1, R3, R4, and R5, these results are expected due to those groups are divided into many branches in the system. The top event probability is obtained as 446. 


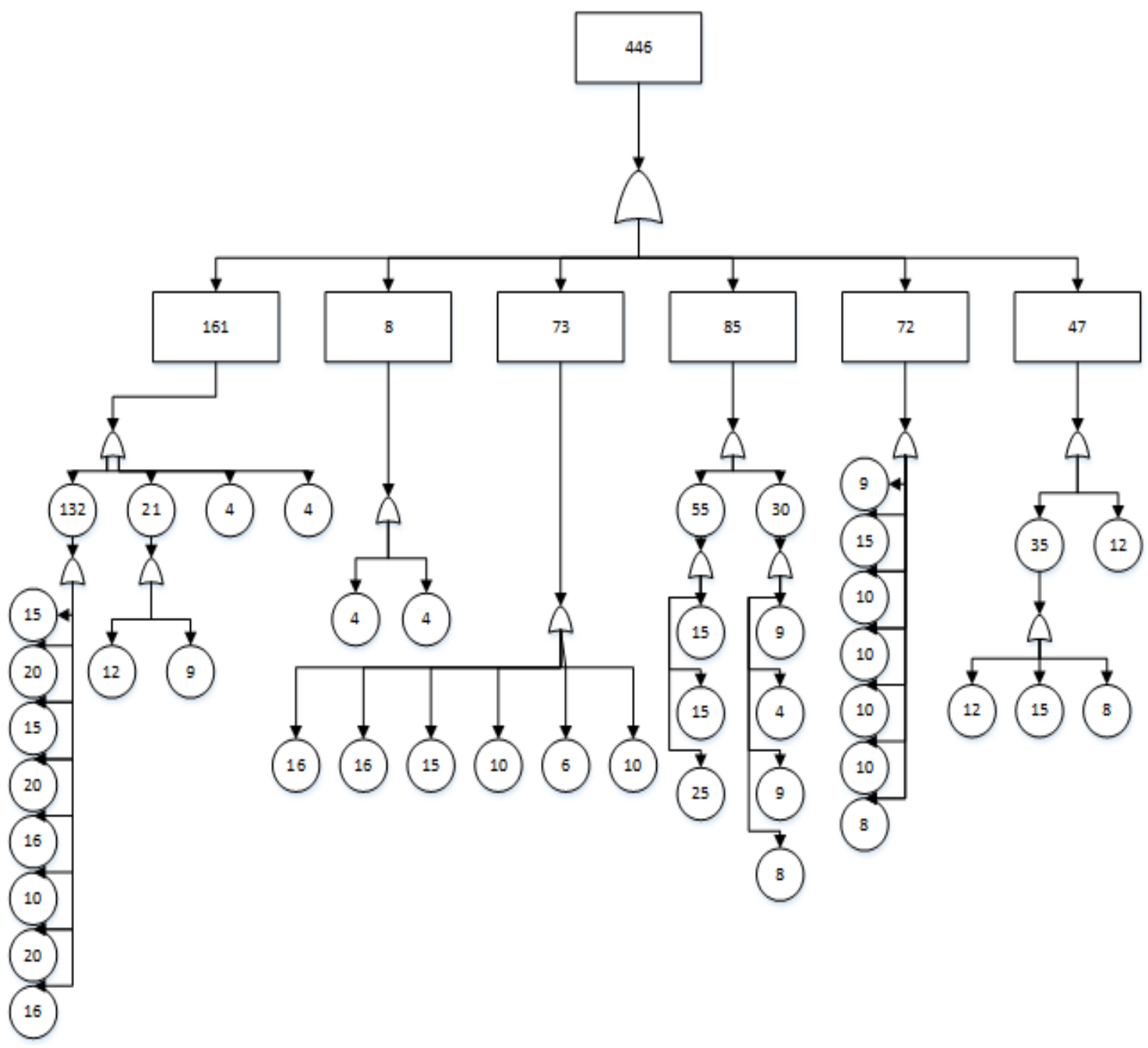

Figure 4. Results of FTA based on $5 X 5$ Matrix

The new risk scores through taking measures for the risks using the $5 \times 5$ matrix are given in Table 3 . The highest values obtained for the first application of the $5 \times 5$ matrix are decreases with some measures. A comparison of the first results in the system given in Table 2 and the results given in Table 3 demonstrates the effectiveness of the taking measures.

Table 3. Measures for risks

\begin{tabular}{|c|c|c|c|c|c|c|c|}
\hline 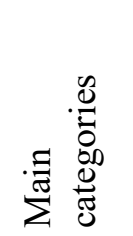 & 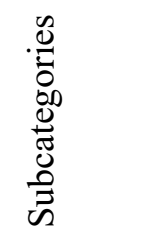 & $\frac{y}{n}$ & 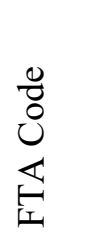 & 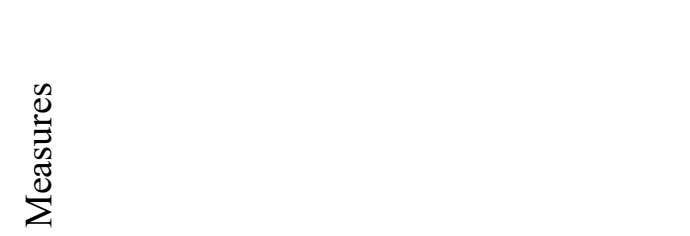 & $\begin{array}{l}\vec{D} \\
0 \\
0 \\
\tilde{D}\end{array}$ & 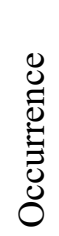 & 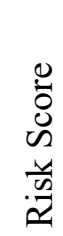 \\
\hline Project & Schedule & S1 & R111 & $\begin{array}{l}\text { 1. Country rating studies and country risk } \\
\text { reports, } \\
\text { 2. Making customer rating work. }\end{array}$ & 5 & 2 & 10 \\
\hline Project & Schedule & $\mathrm{S} 2$ & R112 & 1. Strict enforcement of statutory sanctions & 5 & 2 & 10 \\
\hline Project & Schedule & S3 & R113 & $\begin{array}{l}\text { 1. Provision of more approved suppliers } \\
\text { providing the necessary conditions } \\
\text { 2. Interactive communication of the project } \\
\text { team to approve the approved supplier list } \\
\text { with the Employer }\end{array}$ & 5 & 2 & 10 \\
\hline
\end{tabular}




\begin{tabular}{|c|c|c|c|c|c|c|c|}
\hline Project & Schedule & S4 & R114 & 1. Increasing the control of the plans & 5 & 3 & 15 \\
\hline Project & Schedule & S5 & R115 & $\begin{array}{l}\text { 1. Raising awareness for the projects to } \\
\text { understand the importance of sticking to } \\
\text { the production plan. }\end{array}$ & 4 & 2 & 8 \\
\hline Project & Schedule & S6 & R117 & $\begin{array}{l}\text { 1. Raising awareness for the projects to } \\
\text { understand the importance of sticking to } \\
\text { the production plan. }\end{array}$ & 5 & 2 & 10 \\
\hline Project & $\begin{array}{l}\text { Organization } \\
\text { al }\end{array}$ & S9 & R121 & $\begin{array}{l}\text { 1. Ensuring that projects and customers are } \\
\text { planning to send raw materials / materials } \\
\text { and realizing the awareness of the } \\
\text { operation with the project teams by staying } \\
\text { true to the plan. }\end{array}$ & 4 & 2 & 8 \\
\hline $\begin{array}{l}\text { Environmenta } \\
1\end{array}$ & $\begin{array}{l}\text { Environment } \\
\text { al Factors }\end{array}$ & $\mathrm{S} 15$ & R31 & $\begin{array}{l}\text { 1. Determination of the new Factory } \\
\text { location where the loading to the ship can } \\
\text { be made directly and the realization of the } \\
\text { project. }\end{array}$ & 4 & 2 & 8 \\
\hline $\begin{array}{l}\text { Environmenta } \\
1\end{array}$ & $\begin{array}{l}\text { Environment } \\
\text { al Factors }\end{array}$ & S16 & R32 & $\begin{array}{l}\text { 1. Determination of the new Factory } \\
\text { location where the ship can be loaded } \\
\text { directly and the realization of the project } \\
\text { (The total duration of the project will be } 1 \text { - } \\
1.5 \text { years, after } 6 \text { months, the new building } \\
\text { can be started, without loss of work) }\end{array}$ & 4 & 2 & 8 \\
\hline \multirow[t]{2}{*}{ Monetary } & Economical & $\mathrm{S} 22$ & R412 & $\begin{array}{l}\text { 1. Increasing and evaluating the number of } \\
\text { alternative suppliers }\end{array}$ & 3 & 3 & 9 \\
\hline & & $\mathrm{S} 23$ & $\mathrm{R} 413$ & $\begin{array}{l}\text { 1. Carrying out business development } \\
\text { activities on alternative sectors, }\end{array}$ & 5 & 2 & 10 \\
\hline Monetary & Economical & & & $\begin{array}{l}\text { 2. Providing a new structure where high } \\
\text { tonnage production and logistics process } \\
\text { can be carried out on the sea shore in order } \\
\text { to meet the demands from different sectors. }\end{array}$ & & & \\
\hline Monetary & Financial & $\mathrm{S} 24$ & $\mathrm{R} 421$ & $\begin{array}{l}\text { 1. Increasing the coordination with the } \\
\text { Central Purchasing Department to make the } \\
\text { payment method as stated in the offer. } \\
\text { 2. Creating cash flow tables within the } \\
\text { scope of liquidity management and } \\
\text { transferring all the planning in the proposal } \\
\text { process to the system, monitoring this by } \\
\text { MSA and Finance and ensuring that the } \\
\text { payment method is adhered to. }\end{array}$ & 3 & 2 & 6 \\
\hline Monetary & Financial & $\mathrm{S} 26$ & $\mathrm{R} 423$ & $\begin{array}{l}\text { 1. Providing the necessary infrastructure to } \\
\text { provide budget / realization reporting. } \\
2 \text {. Making pipe cost analysis on the system }\end{array}$ & 3 & 2 & 6 \\
\hline Human & $\begin{array}{l}\text { Human } \\
\text { Factors }\end{array}$ & $\mathrm{S} 28$ & R51 & $\begin{array}{l}\text { 1. Receiving consultancy service in order } \\
\text { to ensure that the legislative follow-up } \\
\text { regarding the relevant law is carried out } \\
\text { regularly at the Holding level, } \\
\text { 2. Making decisions parallel to the law on } \\
\text { data retention in terms of Information } \\
\text { Technologies } \\
\text { 3. Analyzing the legally required data for } \\
\text { all units, preparing deletion actions related } \\
\text { to non-essential data }\end{array}$ & 3 & 2 & 6 \\
\hline Human & $\begin{array}{l}\text { Human } \\
\text { Factors }\end{array}$ & S29 & R52 & $\begin{array}{l}\text { 1. To instruct the relevant department } \\
\text { managers to use the accumulated leave }\end{array}$ & 5 & 2 & 10 \\
\hline
\end{tabular}




\begin{tabular}{cccccccc}
\hline & \multicolumn{7}{c}{$\begin{array}{l}\text { days by checking the leave balances of the } \\
\text { employees annually. }\end{array}$} \\
Supply Chain & Machinery & S36 & R612 & $\begin{array}{l}\text { 1. Performing follow-up analysis and } \\
\text { reporting of current versions }\end{array}$ & 5 & 2 & 10 \\
Supply Chain & Procurement & S38 & R62 & $\begin{array}{l}\text { 1. Complete and implement the installation } \\
\text { of the Management System }\end{array}$ & 4 & 2 & 8 \\
\hline
\end{tabular}

Figure 5 depicts the results of recreating the fault tree with new $5 \times 5$ matrix scores. The top event probability is decreased to 339. Risks with the highest value are R114, R118, R33, and R411. Approximately 24\% improvement is obtained, and it can be said that this improvement is very important for the general structure of the company and will enable it to manage its business more effectively.

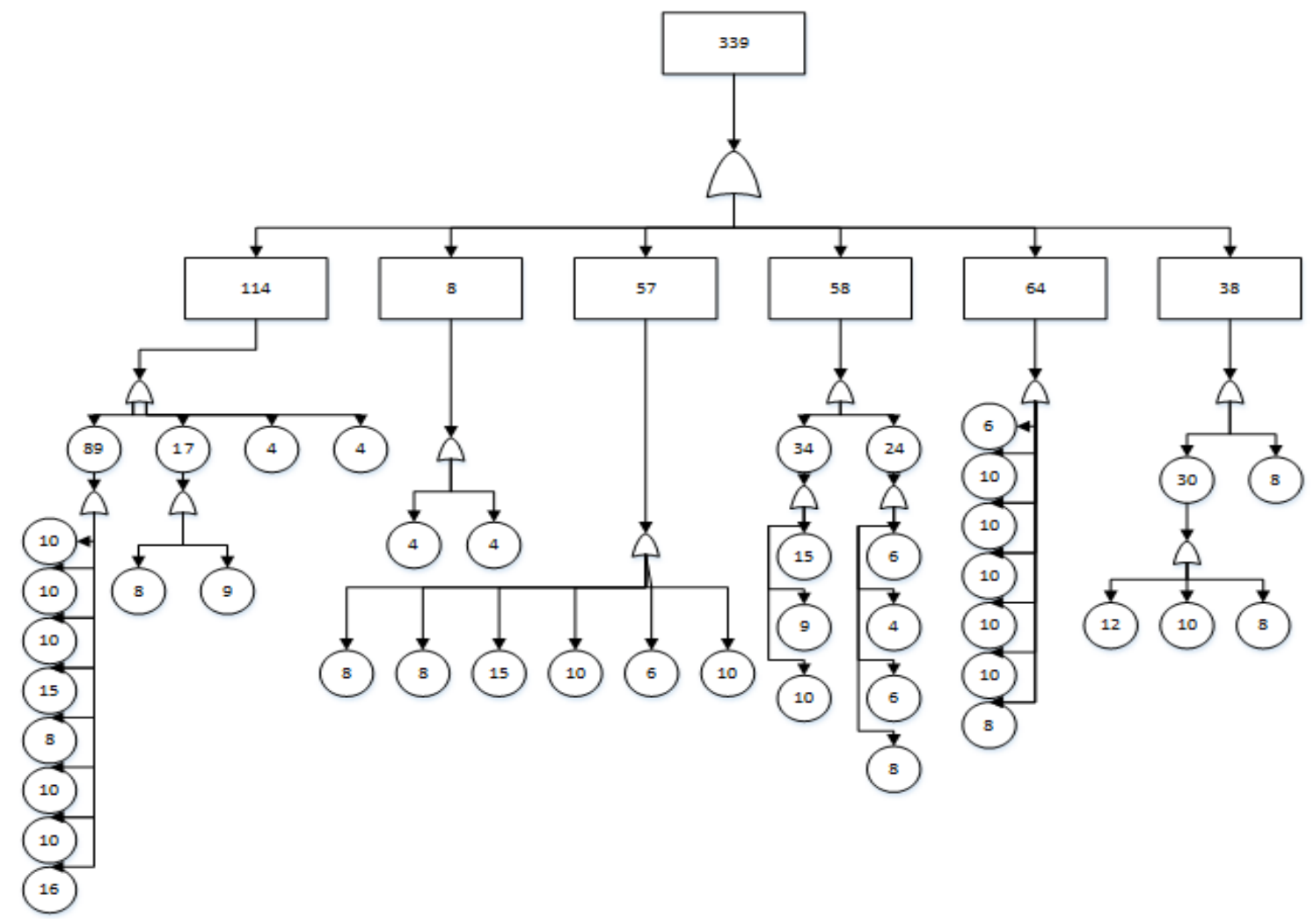

Figure 5. New risk scores with $5 \times 5$ matrix-based FTA

\section{MANAGERIAL INSIGHTS (YÖNETIMSEL ÇIKARIMLAR)}

Project-based enterprises are encouraged to develop effective risk management tools. According to the results and discussions, some managerial insights are presented in the following:

- Production schedule regarding pipeline, fittings, steel materials availability is followed continuously.

- Supplier alternatives are enlarged for decision changes

- Stock control of spare parts required for CNC machines is followed to prevent the inventory decreasing and increasing situations.

- Implementation of effective contract management with subcontractors to fulfil their legal obligations is conducted.

- Economic, political, and military situations of the country where the project is conducted are analysed before the starting phase of project

- Risks are defined in the revision request process in detailed.

- New requirements and changes in trends are followed to prevent the loss of project opportunity

- The manufacturing site at the port is planned to evaluate the logistics constraints. 


\section{CONCLUSIONS (SONUÇLAR)}

In project-based enterprises, changing conditions and risks must be managed correctly to provide customer satisfaction and competitive advantage. In recent years, the importance of integrated risk methods has shown a substantial increase. Thus, state-of-art methods are hot research topics for both project-based firms and researchers dealing with project risks. Effective management of political \& geographical, project, environmental, monetary, human, supply chain risks of the enterprises is important. In this context, the combination method of the FD and integrated FTA-5x5 matrix achieves the comprehensive risk management to define the risk levels. First, the risks are divided into root causes with FD for the enterprise. Then, 5x5 Matrix and FTA methods have been applied to evaluate these risks, in which FTA is performed that results with failure modes and 5x5 matrix are used for ranking these failure modes. This is not only an analysis of fishbone root causes and risks related to the hazards, probabilities of faults but also to provide a comprehensive approach regarding the analysis of the high-level risks. The integrated approach can guide decision-makers to prioritize the risks to take effective measures and use budget efficiently. For future works, different state of the art MCDM approaches to validate the results could be used under fuzzy environment. The effects of the high-level risks on the other measures can be examined.

\section{CONFLICT OF INTEREST (ÇIKAR ÇATIŞMASI)}

There is no conflict of interest.

\section{REFERENCES (KAYNAKLAR)}

[1] T. Luo, C. Wu, L. Duan. Fishbone diagram and risk matrix analysis method and its application in safety assessment of natural gas spherical tank. Journal of cleaner production, 174 (2018) 296-304.

[2] G. Ilie, C. N. Ciocoiu. Application of fishbone diagram to determine the risk of an event with multiple causes. Management research and practice, 2:1 (2010) 1-20.

[3] B. Bertsche. Reliability in automotive and mechanical engineering: determination of component and system reliability. Springer Science \& Business Media, 2008.

[4] O. Derse, E. Göçmen. Transportation mode choice using fault tree analysis and mathematical modeling approach. Journal of transportation safety \& security, 13:6 (2021) 642-660.

[5] X. Zhang, Y. Li, Y. Ran, G. Zhang. A hybrid multilevel FTA-FMEA method for a flexible manufacturing cell based on meta-action and TOPSIS, IEEE access, 7(2019) 110306-110315

[6] Z. Bluvband, R. Polak, P. Grabov. Bouncing failure analysis (BFA): the unified FTA-FMEA methodology, Annual reliability and maintainability symposium, (2005) 463-467.

[7] M. Shafiee, E. Enjema, A. Kolios. An integrated FTA-FMEA model for risk analysis of engineering systems: a case study of subsea blowout preventers. Applied sciences, 9:6 (2019) 1192.

[8] L. E. G. Martins, T. Gorschek. Requirements engineering for safety-critical systems: overview and challenges. IEEE software 34:4 (2017) 49-57.

[9] J. F. W. Peeters, R. J. Basten, T. Tinga. Improving failure analysis efficiency by combining FTA and FMEA in a recursive manner. Reliability engineering \& system safety, 172 (2018) 36-44.

[10] N. G. Mutlu. S. Altuntas. Hazard and risk analysis for ring spinning yarn production process by integrated FTA-FMEA approach. Journal of Textile \& Apparel/Tekstil ve Konfeksiyon, 29:3 (2019) 208-218.

[11] S. Yu, J. Liu, Q. Yang, M. Pan. A comparison of FMEA, AFMEA and FTA, The proceedings of 2011 9th international conference on reliability, maintainability and safety, (2011) 954-960. 
[12] M. Yazdi, O. Korhan, S. Daneshvar. Application of fuzzy fault tree analysis based on modified fuzzy AHP and fuzzy TOPSIS for fire and explosion in the process industry. International journal of occupational safety and ergonomics, 26:2 (2020) 319-335.

[13] H. Yin, C. Liu, W. Wu, K. Song, D. Liu, Y. Dan. Safety assessment of natural gas storage tank using similarity aggregation method based fuzzy fault tree analysis (SAM-FFTA) approach. Journal of loss prevention in the process industries, 66 (2020) 104159.

[14] H. Wang, X. Lu, Y. Du, C. Zhang, R. Sadiq, Y. Deng, Y. Fault tree analysis based on TOPSIS and triangular fuzzy number. International journal of system assurance engineering and management, 8:4 (2017) 2064-2070.

[15] M. Arief, Y. Latief. Project planning system improvement in residential development project: a risk analysis. IOP conference series: materials science and engineering, 1098:2 (2021) 022032.

[16] H. Etemadinia, M. Tavakolan. Using a hybrid system dynamic and interpretive structural modeling for risk analysis of design phase of the construction projects. International journal of construction management, 21:1 (2021) 93-112.

[17] C. Dağsuyu, E. Göçmen, M. Narlı, A. Kokangül. Classical and fuzzy FMEA risk analysis in a sterilization unit. Computers \& industrial engineering, 101 (2016) 286-294.

[18] M. Narl1, E. Göçmen, O. Derse. Risk assessment using a novel hybrid method: a case study at the biochemistry department. Hacettepe sağlık idaresi dergisi, 24:3 (2021) 571-588.

[19] M. Bertolini, A. Rizzi, M. Bevilacqua. An alternative approach to HACCP system implementation. Journal of food engineering, 79:4 (2007) 1322-1328.

[20] W.-S., Lee, D. L. Grosh, F. A. Tillman, C. H. Lie. Fault tree analysis, methods, and applications: a review. IEEE transactions on reliability, 34:3 (1985) 194-203.

[21] Y. N. Hu. Research on the application of fault tree analysis for building fire safety of hotels. Procedia engineering, 135 (2016) 524-530.

[22] A. S. Cheliyan, S. K. Bhattacharyya. Fuzzy fault tree analysis of oil and gas leak- age in subsea production systems. Journal of ocean engineering and science, 3:1: (2018) 38-48.

[23] J. Kang, L. Sun, C. G. Soares. Fault tree analysis of floating offshore wind turbines. Renewable energy, 133 (2019) 1455-1467. 